\title{
Initiate of digital village for excellence service in archipelago area
}

\author{
Mohammad Hidayaturrahman ${ }^{a, 1,{ }^{*}, \text { Edy Purwanto }}{ }^{\mathrm{b}, 2}$ \\ ${ }^{a}$ Faculty of Social and Political Sciences, Universitas Wiraraja, Jl. Raya Sumenep-Pamekasan KM. 05 Patean, Panitian Utara, Patean, Batuan, \\ Kabupaten Sumenep, East Java 69451 Indonesia \\ ${ }^{b}$ Faculty of Economics and Business, Universitas Wiraraja, JI. Raya Sumenep-Pamekasan KM. 05 Patean, Panitian Utara, Patean, Batuan, \\ Kabupaten Sumenep, East Java 69451 Indonesia \\ ${ }^{1}$ hidayaturrahman@wiraraja.ac.id, ${ }^{2}$ edhyaz@gmail.com \\ * Corresponding author
}

\begin{tabular}{|c|c|}
\hline ARTICLE INFO & ABSTRACT \\
\hline $\begin{array}{l}\text { Article history } \\
\text { Received: 2020-08-31 } \\
\text { Revised: 2020-10-24 } \\
\text { Accepted: 2020-12-15 } \\
\text { Published: 2020-12-29 } \\
\text { Keywords } \\
\text { Archipelago area } \\
\text { Digital village } \\
\text { Excellence service }\end{array}$ & $\begin{array}{l}\text { Public services in Pagerungan Island / Village, Sapeken District, Sumenep Regency, East Java still use } \\
\text { a manual system. This condition is troublesome for government officials and citizens who want to } \\
\text { get services. On the other hand, the global world and the Indonesian government have launched } \\
\text { Sustainable Development Goals (SDGs), the ninth goal is development based on technological } \\
\text { progress. One of the efforts made to make this happen is by initiating a digital village (or Desa } \\
\text { Digital/DEDI) in the archipelago. DEDI is a form of digital-based village administration service, using } \\
\text { gadgets owned by residents connected to applications that are centralized in the village office. The } \\
\text { pioneering of a digital village was carried out through socialization and focus group discussions (FGD) } \\
\text { which were carried out with village government officials from the village head, village officials, to } \\
\text { neighborhood associations. Equalizing perceptions and desires, so that the digital village began to } \\
\text { be initiated through village meetings to be implemented starting in 2020. To make it work effectively, } \\
\text { mentoring is carried out, related to making programs, modules, and transfer of technology to officers } \\
\text { and community units). Digital villages are implemented using village funds in } 2020 \text { and } 2021 \text {. } \\
\text { This is an open access article under the CC-BY-SA license }\end{array}$ \\
\hline D) Check for updates & (c) (†) (ஒ) \\
\hline
\end{tabular}

How to cite: Hidayaturrahman, M. \& Purwanto, E. (2020). Initiate of digital village for excellence service in archipelago area. Journal of Community Service and Empowerment, 1(3), 121-127. doi: https://doi.org/10.22219/jcse.v1i3.13467

\section{PENDAHULUAN}

Madura merupakan salah satu wilayah yang dikenal memiliki sumber daya alam (natural resources), terutama minyak alam dan gas bumi (migas). Dari empat kabupaten yang ada di Madura, yaitu Bangkalan, Sampang, Pamekasan dan Sumenep, hampir seluruhnya terdapat perusahaan migas yang melakukan kegiatan eksplorasi maupun produksi. hanya Kabupaten Pamekasan yang belum memiliki perusahaan migas yang melakukan kegiatan produksi, meski ada juga yang menyebut bahwa Kabupaten Pamekasan memiliki kandungan sumber daya alam, terutama migas. Namun hingga kini, belum ada kegiatan produksi migas di Kabupaten Pamekasan. Artinya pendapatan asli daerah (PAD) maupun sumber lain yang berasal dari migas di Kabupaten Pamekasan tidak ada sama sekali (R. L. Sari \& Khoirudin, 2019).

Begitu pula dengan kondisi sumber daya manusia (SDM) dan tingkat pendidikan atau lama sekolah, kabupaten daerah penghasil migas di Madura tidak lebih baik kondisinya dibandingkan dengan daerah yang bukan penghasil migas. Di Kabupaten Sampang, sebagai salah satu daerah penghasil migas di Madura, tingkat pendidikan warganya, rata-rata tidak lulus sekolah dasar (SD) atau rata-rata lama penduduknya bersekolah hanya empat tahun. Begitu pula dengan kabupaten lain yaitu Kabupaten Bangkalan dan Kabupaten Sumenep rata-rata lama penduduk bersekolah adalah lima tahun, atau sama dengan tidak lulus sekolah dasar (SD). Kondisi tersebut lebih rendah dari tingkat pendidikan dengan Kabupaten Pamekasan yang termasuk bukan daerah penghasil migas. Di Pamekasan, rata-rata penduduknya sudah lulus sekolah 
dasar (SD) atau sama dengan bersekolah enam tahun lebih. Meski tetap masih minim, namun pendidikan di Pamekasan lebih baik dari tiga kabupaten lain yang merupakan kabupaten penghasil migas di Madura (Hidayaturrahman, 2018).

Beragam program pembangunan dan pelayanan telah dilakukan oleh pemerintah termasuk juga dilaksanakan oleh perusahaan swasta untuk mengatasi persoalan pembangunan dan pelayanan di wilayah kepulauan yang memiliki sumber daya alam migas. Salah satunya adalah program pengadaan listrik di wilayah Kecamatan Sapeken dan Kecamatan Raas, Kabupaten Sumenep yang memiliki sumber daya alam migas. Hal tersebut dilakukan untuk menfasilitasi kegiatan belajar siswa pada malam hari dan menggerakkan perekonomian warga, termasuk memberi pelayanan publik (Hidayaturrahman, 2017).

Salah satu sasaran pembangunan berkelanjutan (SDGs) adalah pembangunan berbasis pada kemajuan teknologi. Teknologi yang maju membuat program pembangunan dan pelayanan menjadi efektif, efesien dan terukur. Dengan kemajuan teknologi, setiap daerah di Indonesia baik di kota maupun di desa, di daratan maupun di kepulauan diperlakukan sama, tidak ada perbedaan apalagi diskriminasi (Fauzy \& Setyabawana, 2018).

Namun kondisi pelayanan publik di wilayah kepulauan, termasuk desa yang paling dekat dengan perusahaan kegiatan produksi minyak dan gas (migas) di Pulau Pagerungan Besar dan Pagerungan Kecil, Kecamatan Sapeken, Kabupaten Sumenep, Jawa Timur masih belum sesuai dengan harapan dan perkembangan teknologi informasi. Pelayanan publik masih berjalan secara manual, sistem pelayanan juga tidak tertata secara baik dan terukur. Warga yang hendak mengurus berbagai keperluan administrasi mesti bolak-balik datang ke kantor pemerintah untuk mengurus berbagai keperluan administrasi. Kondisi ini membuat proses pelayanan yang semakin lama dan cenderung berbelit. Menjadi fenomena umum pelayanan publik di wilayah terpencil dan kepulauan yang belum menunjukkan perubahan signifikan (Yayat, 2017).

Berita mengenai berbagai pungutan liar yang terjadi di berbagai wilayah kepulauan dan terpencil menjadi hal lumrah. Seperti ditolerir oleh warga dan dibiasakan oleh aparatus pemerintah. Terutama dengan diamnya warga terhadap kebiasaan oknum aparatus pemerintah yang melakukan tindakan pungli terhadap berbagai keperluan administrasi yang diurus oleh warga. Memang nominal tidak seberapa besar, namun jika diakumulasi jumlah tersebut bukan sedikit. Sehingga menciptakan kondisi yang tidak akuntabel bagi penyelenggara pemerintah (Ramadhani, 2017).

Kondisi tersebut memerlukan perubahan untuk memperbaiki pelayanan publik di wilayah kepulauan. Salah satu langkah yang dapat dilakukan adalah dengan merintis hadirnya desa digital (Eprilianto et al., 2020). Desa digital merupakan salah satu upaya menjadikan pelayanan di tingkat desa berbasis digital yang tersambung dengan berbagai kantor pemerintah, baik di tingkat kecamatan maupun kabupaten. Desa digital menjadikan pelayanan lebih murah, efektif dan efesien serta terukur. Oleh karena itu, artikel ini bertujuan menguraikan bagaimana proses pelaksanaan rintisan desa digital di Pulau/ Desa Pagerungan Kecil, Kecamatan Sapeken, Kabupaten Sumenep, Jawa Timur.

\section{METODE}

Lokasi desa digital berada di Pulau/ Desa Pagerungan Kecil, Kecamatan Sapeken, Kabupaten Sumenep, Jawa Timur (Gambar 1). Untuk mencapai Pulau Pagerungan Kecil bisa ditempuh dengan perjalanan laut menggunakan kapal laut. Rute untuk sampai di Pulau Pagerungan Kecil sebagai berikut. Dari Kampus Universitas Wiraraja berkendara sekitar 15 menit menuju Pelabuhan Kalianget. Dari Pelabuhan Kalianget tersedia kapal motor penumpang Dharma Bahari Sumekar yang membawa penumpang dan kendaraan menuju Pulau Sapeken. Lama perjalanan laut dari Pelabuhan Kalianget ke Pulau Sapeken sekira 12 jam. Angkutan kapal dari Kalianget ke Pulau Sapeken tersedia sekali dalam satu minggu.

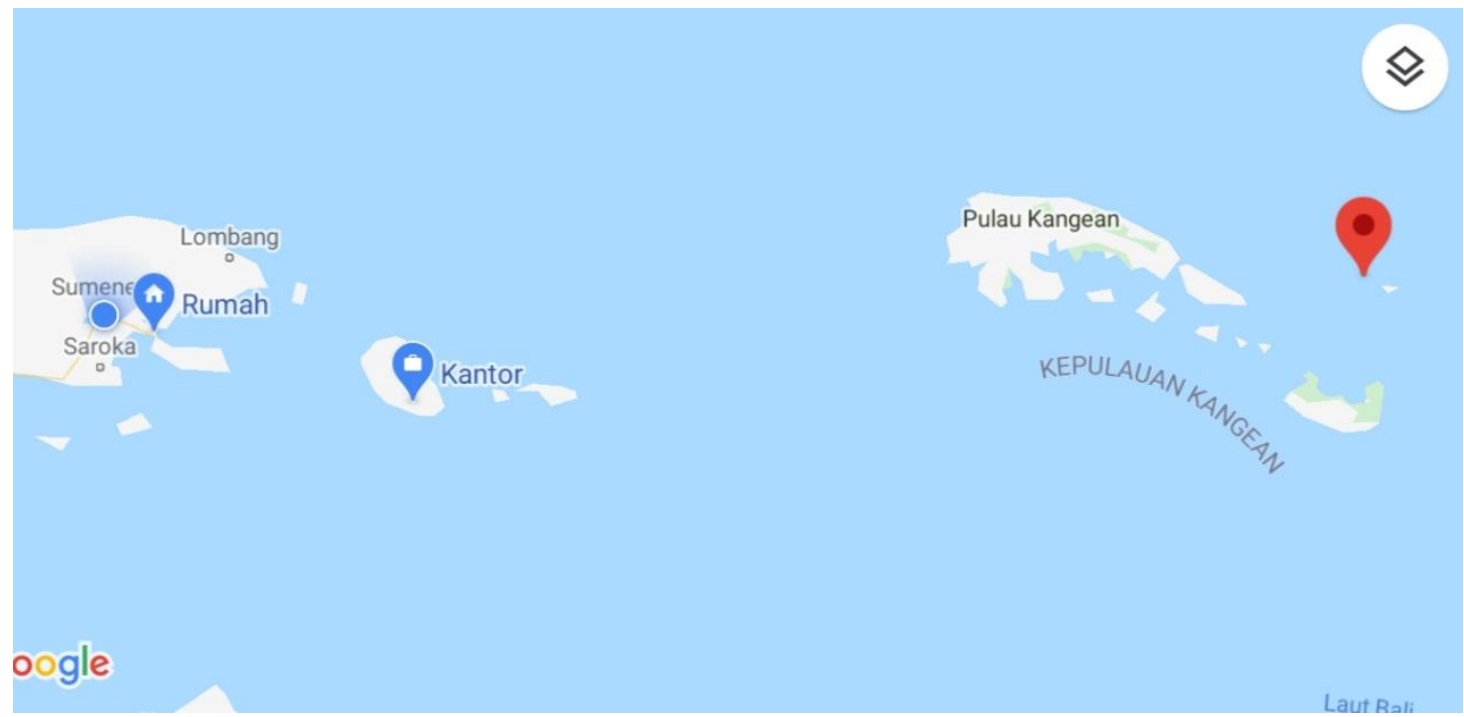

Gambar 1. Peta dan jarak Pulau/ Desa Pagerungan Kecil, Kecamatan Sapeken, Kabupaten Sumenep. (Sumber: Dokumen penulis, 2020). 
Dari Dermaga Pulau Sapeken kemudian melanjutkan perjalanan ke Pulau Pagerungan Kecil menggunakan perahu kayu dengan jarak tempuh sekira dua jam perjalanan laut. Untuk mencapai Pulau Pagerungan Kecil bisa juga menggunakan pesawat dari Bandara Trunojoyo Sumenep, ke Bandara milik perusahaan migas Kangean Energy Indonesia (KEI) yang berada di Pulau Pagerungan Besar, Kecamatan Sapeken. Jarak tempuh perjalanan udara dari Bandara Trunojoyo ke Bandara di Pulau Pagerungan Besar sekira 60 menit (Gambar 2). Dari Pulau Pagerungan Besar melanjutkan perjalanan menggunakan perahu kayu menuju Pulau Pagerungan Kecil selama 30 menit. Pesawat dari Bandara Trunojoyo Sumenep ke Bandara Pagerungan Besar beroperasi setiap hari Rabu, atau sepekan sekali (Gambar 3).

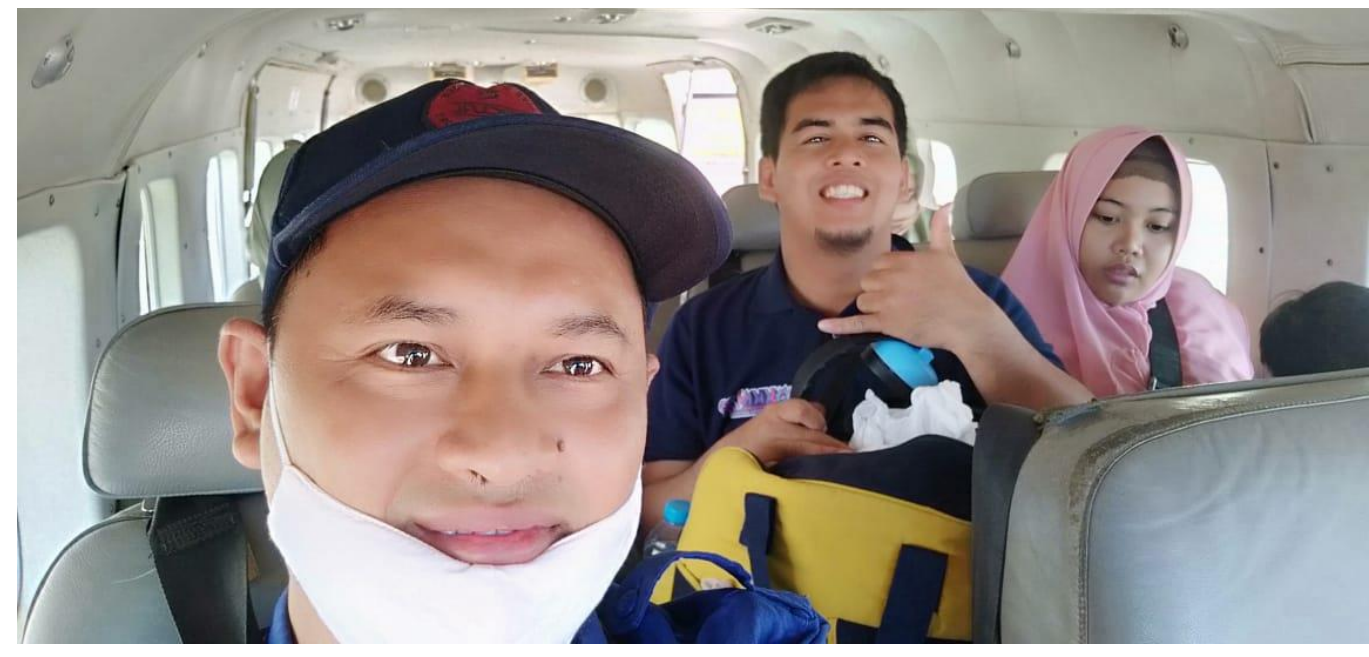

Gambar 2. Tim pengabdi menggunakan pesawat kecil bermuatan 11 orang dari Sumenep ke Pagerungan Besar. (Sumber: Dokumen pribadi, 2020).

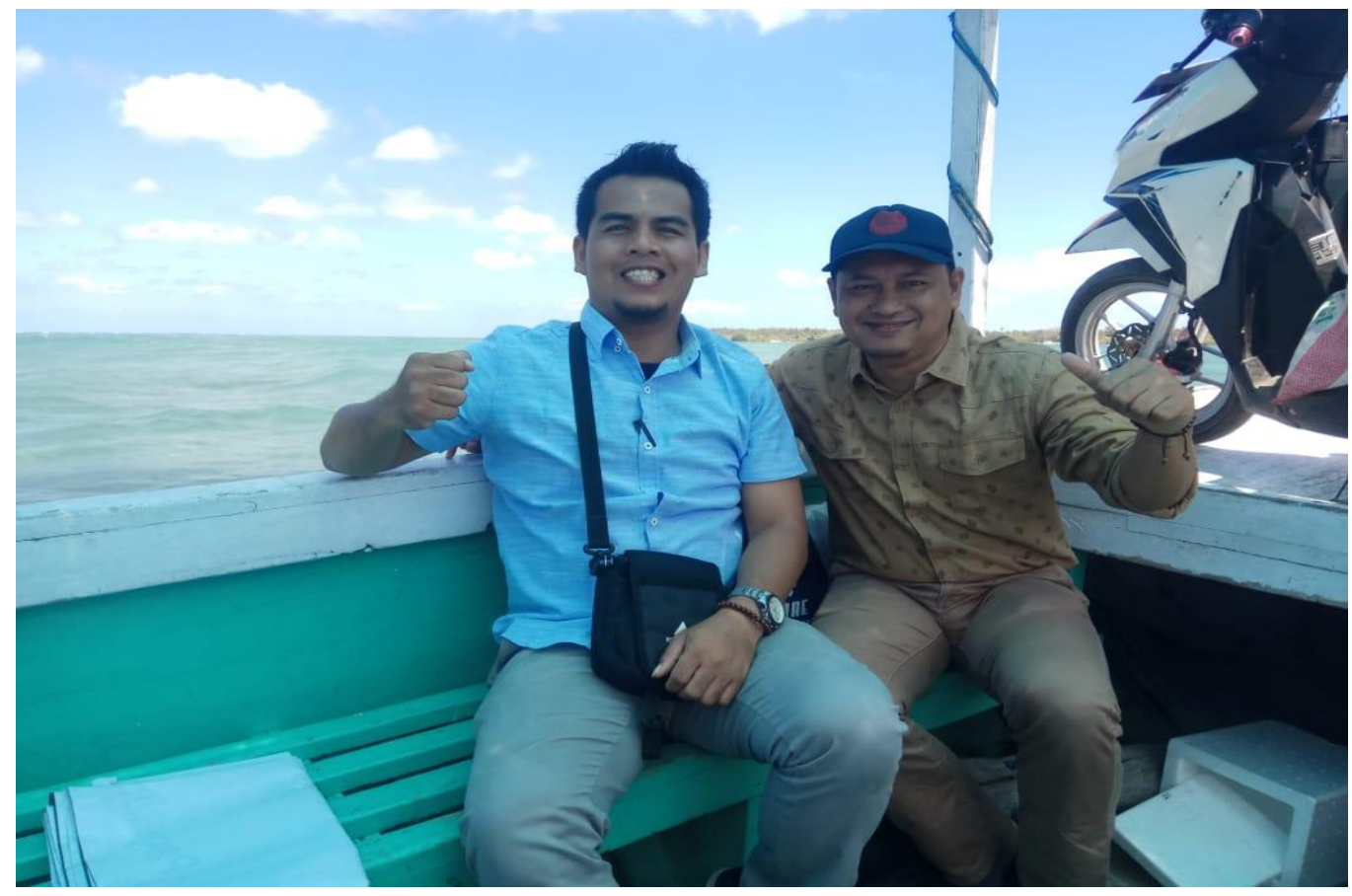

Gambar 3. Tim pengabdi berada di atas perahu yang menghubungkan Pulau Pagerungan Besar dengan Pulau Pageruangan Kecil, Kecamatan Sapeken, Kabupaten Sumenep, Jawa Timur. Sumber: Dokumen pribadi, 2020).

Pendekatan yang digunakan dalam pelaksanaan pengabdian ini lebih berorientasi pada partisipatif, dengan kemitraan dan pendampingan. Model pembangunan kemitraan memungkinkan tercapainya tujuan pembangunan yang lebih merata, menyentuh langsung pada sasaran yang melibatkan lebih banyak lagi mitra (Pratama, 2020). Sasaran pembangunan tidak semata-semata menjadi objek pembangunan, tapi juga menjadi pelaku (subjek) pembangunan (Setyowati, 2019). 
Model pendampingan memungkinkan terarahnya program yang dibuat. Pola pelaksanaan program dilakukan secara kontinyu dan terkontrol. Tahapan demi tahapan dapat dipantau dan dikontrol secara baik dan detil. Jika ada hal yang tidak sesuai dapat langsung diperbaiki pada saat ditemukan sejak awal. Sehingga tidak ada pembiaran yang menyebabkan program semakin jauh melenceng dari panduan yang sudah ditetapkan (Y. P. Sari et al., 2019). Pendampingan yang dilakukan meliputi berbagai tahapan. Pertama, sosialisasi. Kegiatan sosialisasi merupakan bagian dari pengenalan yang dilakukan terhadap objek/ sasaran kegiatan. Sosialisasi dilakukan untuk memberi informasi, pengetahuan dan pemahaman. Dari kegiatan sosialisasi diharapkan ada kesamaan persepsi mengenal yang dibahas dan diperbincangkan atau yang akan dilakukan. Persamaan pemahaman atau mendekatnya pemahaman yang diperoleh dari kegiatan sosialisasi, selanjutnya akan mendekatkan persepsi di antara sesama pelaksana (aktor) kegiatan. Sehingga ke depan kesalahpahaman pada saat pelaksanaan program dapat diminalisasi (Febriadi \& Nasution, 2017). Pada tahap ini aparatus pemerintah diundang bertemu di balai desa pada tanggal 21 Agustus 2020. Dipimpin kepala desa, para aparatus pemerintah desa, hingga rukun warga dan rukun tetangga (RW-RT), mendapatkan sosialisasi pentingnya desa digital bagi pelayanan warga dan pembangunan desa.

Kedua, focus group discussion (FGD). FGD merupakan salah satu pendekatan yang biasa digunakan untuk menganalisis fenomena sosial secara mendalam. Dalam FGD diperoleh data dan informasi dari anggota yang hadir dalam kegiatan FGD (O.Nyumba et al., 2018). FGD biasanya dilakukan sebagai penajaman terhadap pembacaan fenomena sosial yang ada. Hal ini dilakukan untuk menfokuskan pembahasan, mengenai langkah dan tahapan pelaksanaan desa digital. Pada kesempatan FGD tersebut disekapati pula, pihak desa menyediakan sumber daya manusia pelaksana, sedangkan pembuatan program dan aplikasi dilakukan pendampingan oleh pihak Universitas Wiraraja. Adapun dana yang dibutuhkan akan dialokasikan dari dana kemitraan yang berasal dari corporate social responsibility (CSR) perusahaan minyak dan gas (migas) Kangean Energy Indonesia (KEI) yang setiap tahun diberikan kepada Desa Pagerungan Kecil.

Ketiga, kegiatan pendampingan dilakukan sampai desa digital betul-betul berjalan secara efektif dan baik. Desa digital ini merupakan program baru ada di wilayah Kabupaten Sumenep, terlebih lagi wilayah kepulauan. Sebagai program rintisan, perlu adanya pendampingan yang cukup instens terhadap para petugas dan aparatus pemerintah desa. Terlebih lagi di desa, belum ada tenaga ahli bidang informasi teknologi (IT) yang secara khusus menangani program digital. Sehingga perlu dilakukan pelatihan dan pendampingan terhadap petugas. Pendampingan dilakukan sebagai upaya tidak hanya melatih aparatus pemerintah, tetapi juga merubah perilaku aparatus pemerintah supaya berorientasi pada paradigma memberi pelayanan prima kepada warga, di samping tentu saja ada proses transfer knowledge dari pendamping kepada para aparatus desa, sehingga untuk selanjutnya aparatus pemerintah secara mandiri melanjutkan program yang telah dilaksanakan (Siswanti et al., 2016).

Desa digital jika dicermati lebih mendekati pada konsep egovernment yang dilaksanakan oleh pemerintah di tingkat desa. Dalam praktiknya egovernment mengurangi kalau tidak bisa menghilangkan sama sekali proses pembuatan surat dengan menggunakan kertas atau paper less (Yamin, 2018). Hal ini secara umum juga sesuai dengan semangat dan konsep SDGs yang lebih ramah terhadap lingkungan (Arian \& Juraida, 2019). Aspek pelayanan di tingkat desa tidak lagi banyak menggunakan dan terintegrasi dalam sistem yang bisa diakses lewat website dan gawai.

\section{HASIL DAN PEMBAHASAN}

\section{Gambaran Desa Digital}

Kegiatan pertama yang dilakukan adalah memberikan sosialisasi tentang gambaran desa digital kepada apparatus desa (Gambar 4).

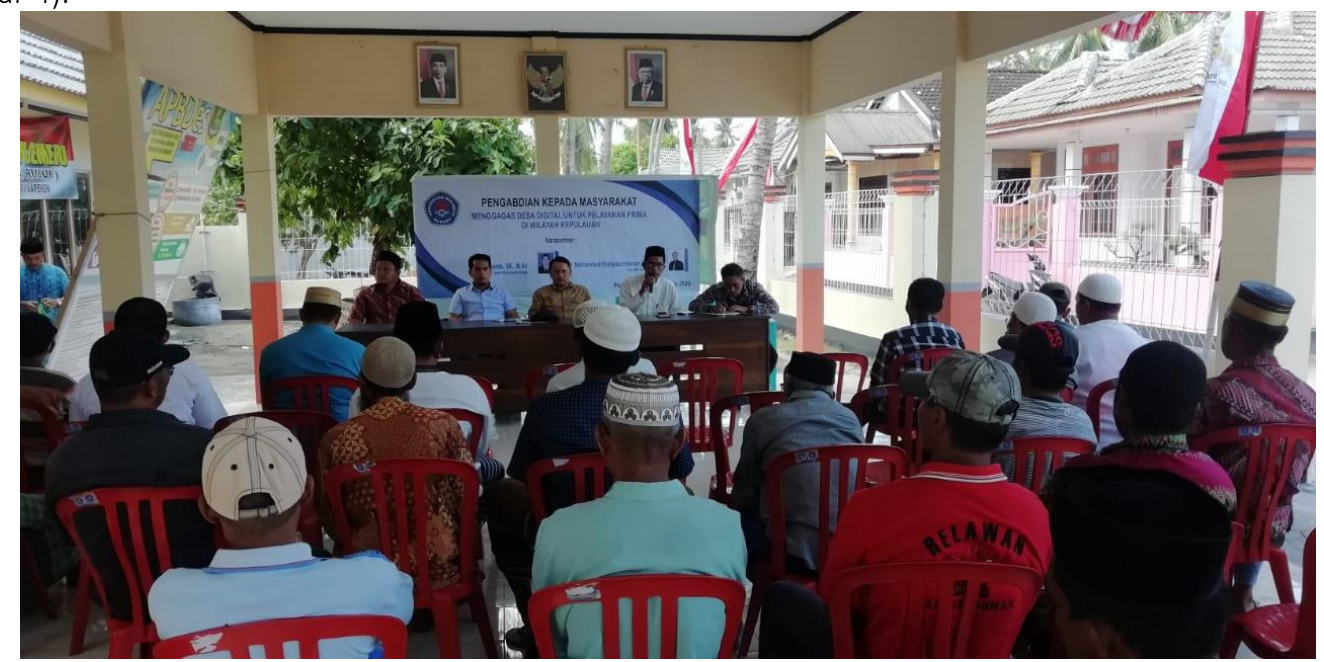

Gambar 4. Tim pengabdi bersama aparatus pemerintah Desa Pagerungan Kecil, Kecamatan Sapeken, Kabupaten Sumenep, Jawa Timur saat melakukan sosialisasi di balai desa setempat. (Sumber: Dokumentasi pribadi, 2020). 
Ilmu pengetahuan dan teknologi (IPTEK) yang ada di dalam kegiatan ini meliputi, kegiatan pelayanan di balai desa secara digital. Aparatus pemerintah melakukan pelayanan di balai desa menggunakan komputer/ monitor tv flat berukuran cukup besar, yang sudah diisi program pelayanan. Perangkat pelayanan juga terintegrasi ke data yang ada di Kabupaten Sumenep maupun Propinsi Jawa Timur dan Pemerintah Pusat. Pada siang hari, listrik belum menyala di Pulau Pagerungan Kecil, Kecamatan Sapeken, hanya menyala pada malam hari. Maka seluruh perangkat pelayanan di balai desa dinyalakan dengan menggunakan solar sel (tenaga surya), sehingga ramah lingkungan dan hemat biaya.

Seluruh materi pelayanan yang akan diberikan oleh desa telah ada di dalam komputer yang sudah diprogram secara khusus. Di dalamnya juga sudah memuat data penduduk desa yang sinkron dengan KTP elektronik berbasis NIK. Sehingga warga yang hendak mengurus berbagai keperluan di desa tinggal memasukkan NIK dan memilih layanan yang diinginkan. Warga yang hendak mengurus keperluan administrasi bisa lebih dulu mengirim berkas yang dibutuhkan melalui aplikasi yang sudah terintegrasi ke komputer di balai desa. Sehingga aparatus bisa terlebih dulu mengecek kesesuaian, tanpa warga datang ke bali desa.

\section{Tahapan Desa Digital}

Pelaksanaan desa digital dilakukan tahapan yang disiapkan secara bertahap, tidak sekaligus secara bersamaan. Tahapan tersebut meliputi berbagai kegiatan yang butuh persiapan dan melibatkan banyak pihak. Tidak hanya pihak pemerintah desa, namun juga pihak lain, yaitu pendamping dari perguruan tinggi dan pihak ketiga sebagai pembuat aplikasi. Selain itu perlu adanya sinkronisasi data yang sudah masuk di desa, dengan pemerintah tingkat kecamatan dan kabupaten, khususnya dinas atau kantor.

Pertama, pengumpulan data warga desa dan profil penduduk. Pengumpulan data ini meliputi data yang berkaitan dengan data kependudukan yang tertera di akta lahir, kartu tanda penduduk (KTP), dan kartu keluarga (KK), yang meliputi nama, Nomor Induk Kependudukan (NIK), alamat tinggal, dan nomor telepon seluler jika ada. Selain itu, data tersebut juga dilengkapi dengan profil penduduk, yang meliputi pekerjaan, dan penjelasan mengenai pekerjaan. Misalnya pekerjaan sebagai nelayan, di dalam profil penduduk dijelaskan jenis nelayan dan alat tangkap yang digunakan serta alat tangkap atau perahu yang dimiliki. Kemudian jika statusnya sebagai kepala rumah tangga, maka disebutkan anggota keluarga yang ikut tinggal bersamanya. Pengumpulan data dan profil penduduk ini dilakukan oleh Rukun Tetangga (RT) yang didampingi oleh Ketua Rukun Warga (RW). Sebelumnya dilakukan pengarahan kepada RT yang melakukan pendataan, data apa saja yang diperlukan untuk didata dan dicatat. Selanjutnya, setelah data terkumpul semua, jika ada perubahan baik tambahan dan pengurangan, akan dilakukan secara online di aplikasi yang sudah tersedia.

Kedua, pembuatan software dan aplikasi desa digital. Selain pendataan, dibuat software dan aplikasi desa digital. Aplikasi ini berisi tool atau perangkat yang menampung seluruh data dan profil penduduk desa, berikut foto dan rumah tinggal serta aset yang dimiliki. Selain menampung data dan profil penduduk desa, sofware dan aplikasi ini berisi layanan administrasi dan kependudukan. Seperti pengajuan surat pindah, surat keterangan, surat pengantar dan berbagai jenis surat-surat lain yang berkaitan dengan wilayah dan otoritas pemerintah desa. Warga yang hendak mengajukan pembuatan surat tersebut, cukup mendatangi rumah ketua RW/ RT untuk mengajukan pembuatan. Selanjutnya ketua RW/ RT mengupload berbagai berkas yang diperlukan ke dalam aplikasi desa digital. Setelah surat yang diperlukan selesai, warga bisa mendapatkannya di ponsel atau gadget masing-masing surat yang dibutuhkan berikut barcode surat, sebagai bukti keaslian surat. Warga kemudian mencetak surat dimaksud tanpa harus datang ke kantor desa. Sehingga layanan ini akan membuat pelayanan lebih efektif dan efesien. Namun jika warga tidak memiliki ponsel atau gadget, bisa datang ke balai desa, memilih surat yang sudah selesai, dan melakukan pelayanan sendiri di balai desa, dengan mencetak di komputer, berupa layar sentuh yang disediakan di balai desa. Jika tidak paham, maka akan diarahkan oleh petugas yang ada di balai desa. Aplikasi ini juga memungkinkan Ketua RT melaporkan warga pendatang yang datang ke desa, untuk dilaporkan kepada kepala desa melalui aplikasi. Dan aplikasi tersebut tersambung ke kantor/ dinas di kabupaten. Kepala desa juga bisa mengecek update pengurusan berbagai surat yang ada di desa, meskipun tidak sedang berada di balai desa, melalui ponsel atau gadget yang didaftarkan sebagai admin.

Ketiga, input data. Data dan profil penduduk yang sudah dikumpulkan oleh ketua RT bersama ketua RW dimasukkan ke dalam database berupa aplikasi yang berpusat di balai desa. Mengimputan data dilakukan oleh petugas yang ditunjuk oleh kepala desa, yang secara khusus mengurusi data dan pengelolaan desa digital. Data yang diinput otomatis tersedia secara online baik di server desa, maupun di website yang desa. Data ini juga terkoneksi ke pemerintah kecamatan dan dinas di kabupaten.

Keempat, pembuatan standar operating procedure (SOP). Setelah data tersedia di dalam database dan aplikasi, maka dibuat SOP pengoperasian yang meliputi pengoperasian yang dilakukan oleh petugas khusus di desa, maupun yang dilakukan oleh ketua RW dan ketua RT. SOP juga disosialisasikan kepada warga desa yang akan menggunakan aplikasi desa digital. Penyediaan standart operating prosedure (SOP) pelayanan yang dilakukan oleh aparatus pemerintah desa yang inovatif, efektif dan efesien, serta memberi layanan prima bagi warga. Sehingga pada akhirnya akan meningkatkan pelayanan prima dan terintegrasi, dan memudahkan pelayanan bagi warga di wilayah kepulauan secara pasti.

Kelima, coaching. Tidak hanya berupa SOP, namun pelatihan juga diberikan kepada petugas dan RT/RW (Gambar 5). Selain pelatihan, juga dilakukan alih teknologi kepada petugas yang terlibat dalam kepengurusan desa digital. Pelatihan 
dilakukan dalam bentuk praktik langsung yang didampingi oleh pembuat aplikasi. Selanjutnya dilakukan simulasi pelaksanaan terhadap berbagai fitur yang berada di desa digital.

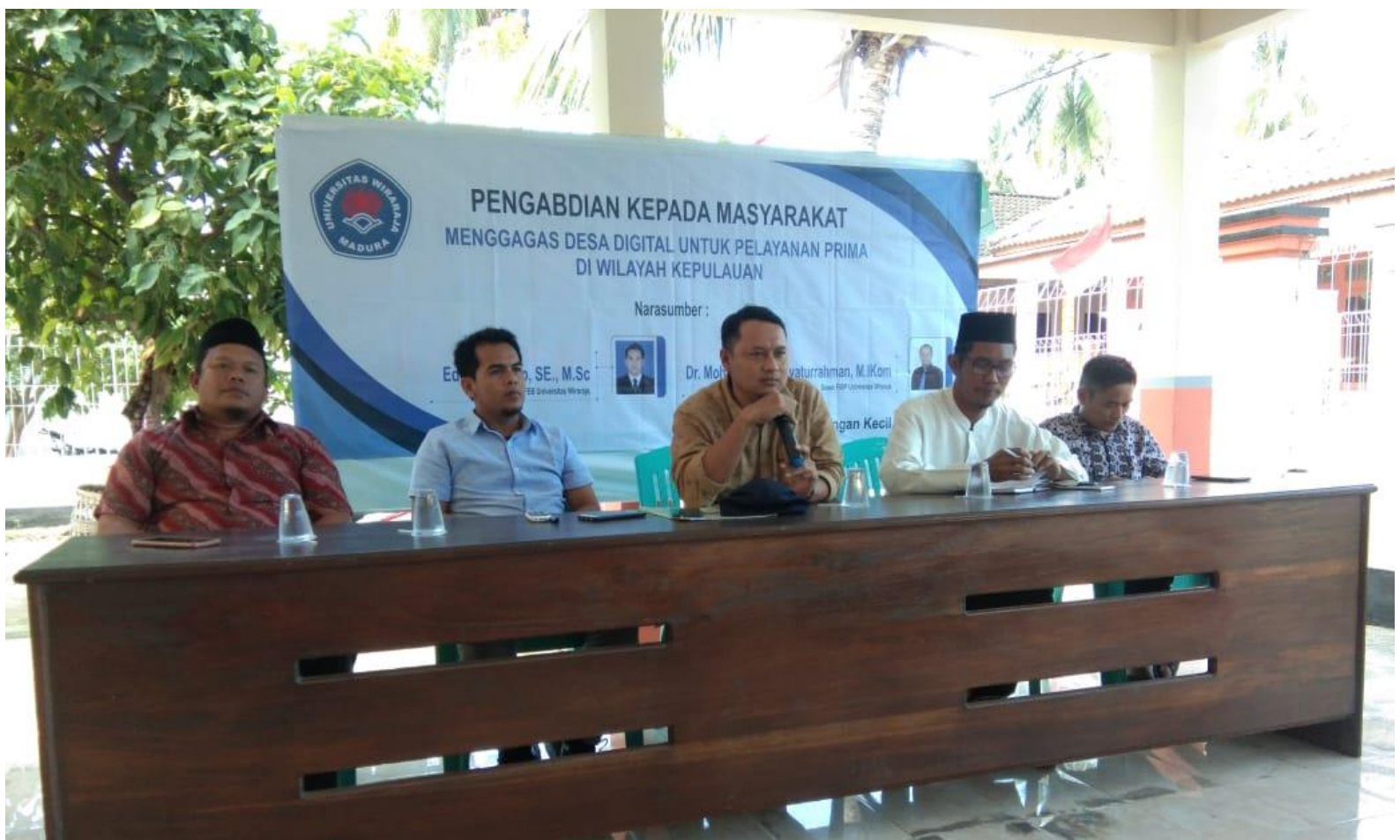

Gambar 5. Suasana focus group discussion (FGD) yang berlangsung di balai desa Pagerungan Kecil, Kecamatan Sapeken, Kabupaten Sumenep, Jawa Timur. (Sumber: Dokumentasi pribadi, 2020).

Keenam, sinkronisasi data ke dinas. Data yang sudah diinput ke database dan aplikasi, selanjutnya dikoneksikan ke dinas yang ada di kantor pemerintah kabupaten dan kantor kecamatan. Data tersebut menjadi bagian dari data yang disetor ke kantor/ dinas di kabupaten. Sehingga tidak perlu lagi melakukan pengajuan data secara manual. Sebab dinas dapat mengambil data yang ada di server desa yang selalu diupdate oleh petugas desa.

Ketujuh. Monitoring. Monitoring terhadap kegiatan pelayanan juga bisa dilakukan dengan cara video conference, dengan begitu tim program melakukan pemantauan sekaligus evaluasi melalui video conference dilakukan dalam waktu yang singkat. Sehingga perkembangan pelayanan dapat dipantau secara baik.

\section{KESIMPULAN}

Desa digital merupakan salah satu upaya yang dilakukan untuk memberi pelayanan yang lebih baik bagi warga kepulauan. Selain itu, desa digital juga mempermudah aparatus pemerintah dalam memberi pelayanan kepada warga desa. Tentu saja juga menghindari berbagai pungutan liar, serta waktu pelayanan yang semakin singkat dan terukur. Desa digital dilaksanakan dengan menggunakan dana desa yang dikelola oleh pemerintah desa.

\section{UCAPAN TERIMA KASIH}

Terima kasih disampaikan kepada Universitas Wiraraja Madura yang telah menyediakan sumber dana untuk keperluan sosialisasi dan pendampingan desa digital di Desa Pagerungan Kecil, Kabupaten Sumenep, Jawa Timur, berupa dana internal tahun 2020.

\section{REFERENSI}

Arian, D., \& Juraida, I. (2019). Eksistensi Perempuan Suku Sasak dalam Pembangunan Berkelanjutan Di Bidang Ekowisata Desa Sembalun Lawang. Community, 5(2), 106-115.

Eprilianto, D. F., Pradana, G. W., \& Sari, Y. E. K. (2020). Digital Inovasi Sektor Publik: Efektivitas Kolaborasi Dalam Implementasi Inovasi Dega Digital. Jurnal EL-RIYASAH, 10(2), 127. https://doi.org/10.24014/jel.v10i2.8909

Fauzy, A., \& Setyabawana, A. P. (2018). Pemanfaatan Data Spasial Untuk Mendukung Tujuan Pembangunan Berkelanjutan (TPB)/ Sustainable Development Goals (SDGS). Mewujudkan Masyarakat Madani Dan Lestari", 1-9.

Febriadi, B., \& Nasution, N. (2017). Sosialisasi Dan Pelatihan Aplikasi Google Form Sebagai Kuisioner Online Untuk Meningkatkan Kualitas Pelayanan. JURNAL INOVTEK POLBENG - SERI INFORMATIKA, 2(1), 68-72. 
http://ejournal.polbeng.ac.id/index.php/ISI/article/view/119/112

Hidayaturrahman, M. (2017). Corporate social responsibility strategi komunikasi perusahaan migas. Jurnal Nomosleca, 3(2), 614-624. https://doi.org/10.26905/nomosleca.v3i2.2036

Hidayaturrahman, M. (2018). Analisis Curse Theory pada Sumber Daya Alam Migas Bagi Warga Madura. Jurnal Studi Agama Dan Masyarakat, 14(01), 12-20. https://doi.org/10.23971/jsam.v14i1.daerah

O.Nyumba, T., Wilson, K., Derrick, C. J., \& Mukherjee, N. (2018). The use of focus group discussion methodology: Insights from two decades of application in conservation. Methods in Ecology and Evolution, 9(1), 20-32. https://doi.org/10.1111/2041$210 X .12860$

Pratama, Y. P. (2020). Konsensus Kemitraan Global Pbb (MDGs \& SDGs), Hipotesis Environmental Kuznet Curve (EKC), dan Degradasi Kualitas Udara di Indonesia Periode 1980-2018. Diponegoro Journal of Economics, 9(4), 1-15.

Ramadhani, W. (2017). Penegakan Hukum Dalam Menanggulangi Pungutan Liar Terhadap Pelayanan Publik. Jurnal Hukum Samudra Keadilan, 12(2), 263-276. https://doi.org/10.2013/jhsk.v12i2.139

Sari, R. L., \& Khoirudin, R. (2019). Determinan Tingkat Kemiskinan di Pulau Madura. Jurnal Manajemen, 9(2), 126-136. https://ejurnal.Ippmunsera.org/index.php/JM/article/view/1741/1114

Sari, Y. P., Farida, I., \& Hetika, H. (2019). Model Pendampingan Umkm Pengolahan Hasil Laut Dengan Metode Pendekatan Pendampingan Terintegrasi. Jurnal Monex, 8(1), 293. https://doi.org/10.30591/monex.v8i1.1269

Setyowati, Y. (2019). Empowerment Communication as a New Perspective of Education Development. Jurnal Komunikasi Pembangunan, 17(2), 188-199.

Siswanti, A. D., Muadi, S., \& Chawa, A. F. (2016). Peran Pendampingan Dalam Program Pemberdayaan Masyarakat (Studi Pada Program Pendampingan Keluarga Balita Gizi Buruk di Kecamatan Semampir Kota Surabaya). Jurnal Wacana, 19(3), $128-137$.

Yamin, M. (2018). Analisis Open Government dan e-Government di Indonesia Berdasarkan Kerangka Kerja Sustainable Development Goals: Studi Kasus Desa Melung, Kabupaten Banyumas. Jurnal Hubungan Internasional, 7(2). https://doi.org/10.18196/hi.72137

Yayat, R. (2017). Kualitas Pelayanan Publik Bidang Administrasi Kependudukan Di Kecamatan Gamping. Jurnal Ilmiah Magister IImu Administrasi (JIMIA), 2, 56-65. http://eprints.uny.ac.id/17523/1/SKRIPSI FULL.pdf 